\title{
PENGELASAN PLAT KAPAL DENGAN VARIASI JENIS ELEKTRODA DAN MEDIA PENDINGIN
}

\author{
Miftakhul Huda*, Sri Mulyo Bondan Respati dan Helmy Purwanto \\ Jurusan Teknik Mesin Fakultas Teknik Universitas Wahid Hasyim Semarang \\ JL. Menoreh Tengah X/22, Semarang 645323, Indonesia \\ *Email: hudarebell.mh@gmail.com
}

\begin{abstract}
ABSTRAK
Dalam proses pengelasan, bagian yang di las menerima panas setempat yang mengakibatkan pengembangan termal, sedangkan bagian yang dingin tidak mengalami perubahan sehingga dapat mengakibatkan ketidak seragaman regangan, hal ini juga berpengaruh terhadap perubahan struktur yang terkandung didalamnya. Maka dari itu pemelihan jenis elektroda serta media pendingin sangat berpengaruh terhadap kekuatan tarik benda dan juga perubahan kandungan struktur yang terjadi di dalamnya. Berdasarkan analisa yang dilakukan, untuk jenis elektroda E6013 NK dengan media pendingin berupa oli, udara, dan air laut, nilai kekuatan tarik tertinggi pada media pendinginan udara yaitu sebesar $57.016 \mathrm{~kg} / \mathrm{mm}^{2}$. Sedangkan untuk jenis elektroda E7018 LB, kekuatan tarik rata-rata tertinggi justru pada jenis pendinginan air laut yang mencapai nilai tegangan tarik hingga $55.228 \mathrm{~kg} / \mathrm{mm}^{2}$. Kandungan Hidrogen rendah sangat baik untuk mencegah deoksidasi pada saat pengelasan, karena baja yang memiliki kadar oksigen tinggi apabila tercampur pada saat proses pengelasan, maka tegangan tariknya akan menurun.
\end{abstract}

Keyword : pengelasan, media pendingin, elektroda, tegangan tarik, struktur mikro

\section{PENDAHULUAN}

Kemajuan teknologi pengelasan akhirakhir ini sangatlah membantu dalam pekerjaan pembuatan konstruksi baik yang sederhana maupun konstruksi yang mempunyai tingkat kesulitan dan persyaratan tinggi. Salah satunya pengelasan SMAW (shield Metal Arc Welding) yaitu pengelasan menggunakan logam berselaput sebagai bahan tambah dengan panas yang didapat dari busur listrik.

Menurut Suprijanto (2013) pengelasan merupakan proses penyambungan dua logam paduan atau lebih yang dilaksanakan dalam keadaan lumer atau cair sehingga setelah membeku akan terbentuk sambungan melalui ikatan kimia yang dihasilkan dari pemakaian energi panas.

Haryadi (2007) media pendingin air tawar dan air laut tidak memberi pengaruh banyak terhadap kekuatan tarik dengan nilai kekuatan tarik antara $29,17 \mathrm{~kg} / \mathrm{mm}^{2}-45,45$ $\mathrm{kg} / \mathrm{mm}^{2}$, namun pengaruh nilai kekerasan antara 137,7 HVN - 244,9 HVN. Akibat proses pengelasan, logam di daerah las mengalami deformasi dan tegangan termal yang berpengaruh pada kekuatan, cacat las dan retak (Supriyanto dkk, 2011)

Pada industri perkapalan, diharapkan seorang juru las haruslah mengetahui tentang kandungan bahan material, serta keadaan logam setelah dilakukan pengelasan termasuk pada proses pendinginannya. Baja ST 60 termasuk baja karbon menengah dengan kadar karbon 0,3-0,6 \% dengan kekuatan tarik maksimum mencapai $60 \mathrm{~kg} / \mathrm{mm}^{2}$. (Sunaryo, 2008)

Plat kapal diklasifikasikan menurut BKI dengan jenis meliputi SS 400, ASTM A57-2, ST 52-3 dan lain-lain dengan tebal: mulai dari $6 \mathrm{~mm} \mathrm{~s} / \mathrm{d} 100 \mathrm{~mm}$, lebar : $1500 \mathrm{~mm} \mathrm{~s} / \mathrm{d} 2700$ $\mathrm{mm}$, panjang : $6 \mathrm{~m} \mathrm{~s} / \mathrm{d} 13 \mathrm{~m}$. Sifat mekanis yang karus dimiliki untuk plat kapal biasa adalah : batas lumer $24 \mathrm{~kg} / \mathrm{mm}^{2}$, kekuatan tarik $41 \mathrm{~kg} / \mathrm{mm}^{2} \mathrm{~s} / \mathrm{d} 50 \mathrm{~kg} / \mathrm{mm}^{2}$, dan regangan patah minimal 22\%.(Dinariyana, 2011)

Tujuan penelitian yang dilakukan adalah mengetahui kekuatan tarik plat baja ST 60, serta analisa struktur mikro terhadap jenis elektroda E 6013 NK dan E 7018 LB dengan media pendingin berupa oli, udara dan air laut, juga uji kelayakan baja St 60 sebagai plat kapal berbagai macam media pendinginan yang dapat digunakan dengan berbagai kandungan menurut viskositasnya :

1. Air Garam $(\rho=1025 \mathrm{~kg} / \mathrm{m} 3, v=1.01$ Pa.s)

2. Air $(\rho=998 \mathrm{~kg} / \mathrm{m} 3, v=1.01$ Pa.s $)$

3. Solar $(\rho=981 \quad \mathrm{~kg} / \mathrm{m} 3, \quad \mathrm{v}=3.25$ Pa.s)

4. Oli $(\rho=981 \mathrm{~kg} / \mathrm{m} 3, v=4.02$ Pa.s $)$

5. Udara $(\rho=1,2 \mathrm{~kg} / \mathrm{m} 3)$ 
Udara tidak memiliki Viskositas tetapi hanya memiliki massa jenis sehingga laju pendinginaannya sangat lambat. (Farida, 2012)

\section{METODE PENELITIAN}

Alur penelitian seperti terlihat pada Gambar 2.

\section{Diagram alir penelitian}

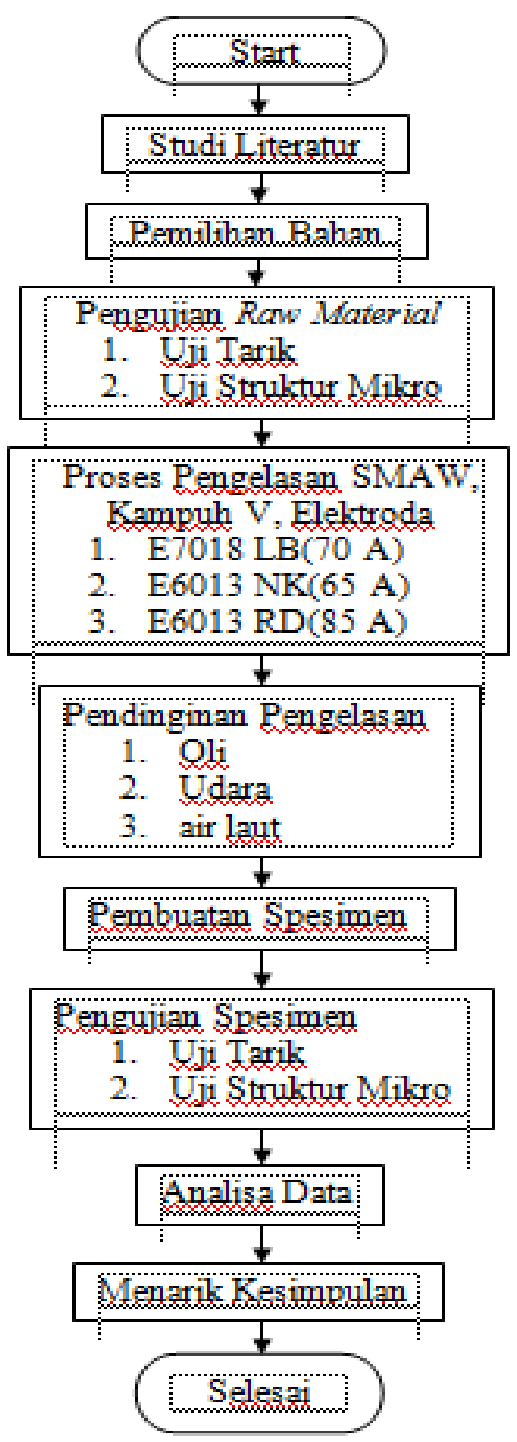

Gambar 1 Diagram Alir Penelitian

Adapun alat dan bahan pada penelitian kali ini adalah Pesawat/mesin las busur jenis Krisbow Rilon ARC 400 G, alat perkakas meja bangku, untuk ahan yang digunakan berupa plat baja jenis St 60, Elektroda E 7018 LB, E 6013 NK dan E 6013 RD

\section{Proses Penelitian}

Studi literatur merupakan metode pengambilan data sekaligus informasi dari buku-buku atau jurnal ilmiah yang kemudian dijadikan sebagai sumber refrensi.

Proses selanjutnya pemilihan bahan berupa baja jenis ST 60 yang dalam standart Jerman dinyatakan jenis baja karbon menengah dengan kekuatan tarik paling tidak $600 \mathrm{~N} / \mathrm{mm}$. Selanjutnya yaitu Pengujian Raw Material dengan tujuan untuk mengetahui nilai dan sifat mekanis dari bahan ST 60. Setelah mengetahui kekuatan tarik material awal, selanjutnya dilakukan proses pengelasan dan pendinginan berupa oli, udara dan air laut.

Untuk standart pengujian pada penelitian ini menggunakan dua jenis spesimen uji yaitu, uji tarik menggunakan standar ASTM E8/E8M09 dan uji struktur mikro.

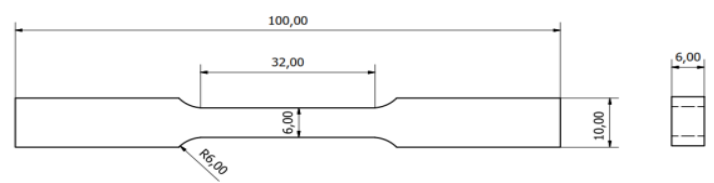

\section{Gambar 2 Standart uji tarik E8/E8M-09}

Setelah dilakukan pengujian selanjutnya dilakukan analisa dari data hasil pengujian tarik dan juga struktur mikro. Untuk tahap akhir yaitu menarik kesimpulan yang berdasarkan dari data hasil pengujian dan analisa

\section{Variabel Dalam Penelitian \\ Variabel dalam penelitian ini adalah sebagai berikut :}

\section{Variabel Bebas}

Spesimen tanpa pengelasan dan perlakuan pendinginan, spesimen dengan pengelasan menggunakan elektroda E7018 LB untuk root weld (penembusan) dan E6013 RD sebagai cuping (penutup) atau sebaliknya namun, digunakan elektroda E6013 NK sebagai root weld dan E7018 LB sebagai cuping dengan pendinginan berupa berupa air laut, oli, dan udara.

\section{Variabel Terikat}

Struktur mikro permukaan, luas penampang, nilai tegangan, nilai regangan, kekuatan tarik

\section{Variabel Kontrol}

Jenis baja yang digunakan untuk spesimen yaitu jenis ST 60 dengan ketebalan $6 \mathrm{~mm}$, dan arus yang digunakan mulai dari 65 hingga 85 ampere. 


\section{HASIL DAN PEMBAHASAN Hasil Pengujian Tarik}

Tabel 1 Hasil pengujian tarik

\begin{tabular}{|c|c|c|c|c|c|c|}
\hline No. & Spesimen & $\begin{array}{l}\text { Area } \\
\left(\mathrm{mm}^{2}\right)\end{array}$ & $\begin{array}{l}\text { Yield stress } \\
\left(\mathrm{Kgf} / \mathrm{mm}^{2}\right)\end{array}$ & $\begin{array}{l}\text { Max load } \\
\left(\mathrm{Kgf} / \mathrm{mm}^{2}\right)\end{array}$ & $\begin{array}{l}\max \text { stress } \\
\left(\mathrm{Kgf} / \mathrm{mm}^{2}\right)\end{array}$ & $\begin{array}{l}\text { elongation } \\
(\%)\end{array}$ \\
\hline 1 & Raw Material & 38.413 & 48.552 & 2208.257 & 57.507 & 51.200 \\
\hline No. & Spesimen & $\begin{array}{l}\text { Area } \\
\left(\mathrm{mm}^{2}\right)\end{array}$ & $\begin{array}{l}\text { Yield stress } \\
\left(\mathrm{Kgf} / \mathrm{mm}^{2}\right)\end{array}$ & $\begin{array}{l}\text { Max load } \\
\left(\mathrm{Kgf} / \mathrm{mm}^{2}\right)\end{array}$ & $\begin{array}{l}\max \text { stress } \\
\left(\mathrm{Kgff} / \mathrm{mm}^{2}\right)\end{array}$ & $\begin{array}{l}\text { elongation } \\
(\%)\end{array}$ \\
\hline 1 & E6013 NK (oli) & 39.307 & 45.362 & 1976.400 & 50.359 & 38.267 \\
\hline 2 & E6013NK (udara) & 39.307 & 51.534 & 2237.580 & 57.016 & 45.483 \\
\hline 3 & E6013 NK (air laut) & 41.540 & 43.362 & 1991.990 & 47.942 & 26.933 \\
\hline
\end{tabular}

\begin{tabular}{|c|c|c|c|c|c|c|}
\hline No. & Spesimen & $\begin{array}{l}\text { Area } \\
\left(\mathrm{mm}^{2}\right)\end{array}$ & $\begin{array}{l}\text { Yield stress } \\
\left(\mathrm{Kgg} / \mathrm{mm}^{2}\right)\end{array}$ & $\begin{array}{l}\text { Max load } \\
\left(\mathrm{Kgf} / \mathrm{mm}^{2}\right)\end{array}$ & $\begin{array}{l}\max \text { stress } \\
\left(\mathrm{Kgg} / \mathrm{mm}^{2}\right)\end{array}$ & $\begin{array}{l}\text { elongation } \\
\text { (\%) }\end{array}$ \\
\hline 1 & E7018 LB (oli) & 41.987 & 40.847 & 1961.207 & 46.551 & 30.667 \\
\hline 2 & E7018 LB (udara) & 44.667 & 46.856 & 2490.717 & 53.808 & 45.717 \\
\hline 3 & E7018 LB (air laut) & 38.190 & 50.000 & 2279.863 & 55.228 & 47.433 \\
\hline
\end{tabular}

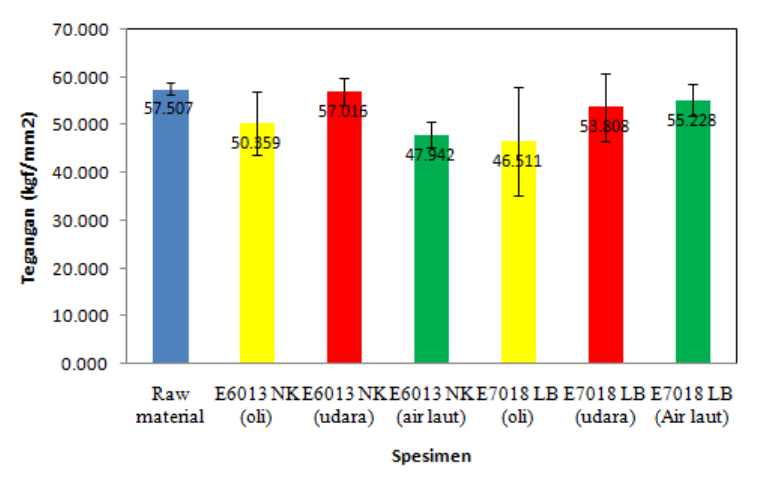

Gambar 3 grafik hasil uji tarik

kekuatan tarik tertinggi pada jenis elektroda E6013 NK yaitu pada pendinginan udara, dimana hasil kekuatan tarik hampir mendekati raw material yang sebesar $57.507 \mathrm{Kg} / \mathrm{mm}^{2}$ dan setelah di lakukan pengelasan serta pendinginan udara, nilai kekuatan tarik berubah menjadi $57.016 \mathrm{Kg} / \mathrm{mm}^{2}$ sedangkan kekuatan tarik terendah pada media pendingin air laut dengan nilai kekuatan tarik sebesar 47.942 hal itu dikarenakan laju pendinginan sangat berpengaruh terhadap hasil pengujian tarik. (Hanafi, 2012). Dapat disimpulkan jika laju pendinginan semakin cepat, maka akan semakin menurunkan kekuatan tarik. Sedangkan pada jenis elektroda E7018 LB nilai kekuatan tarik rata-rata tertinggi justru terjadi pada jenis pendinginan air laut, hal ini di karenakan kandungan fluks yang terdapat pada tipe elektroda E7018 LB berupa serbuk besi yang juga terdapat pula kandungan hidrogen rendah di dalamnya. Sedangkan air laut juga memiliki kadar hidrogen di dalamnya, dimana $\mathrm{H}^{2}$ merupakan reduktor untuk menghilangkan oksigen dari oksida logam contohnya reaksi penghilangan oksigen pada tembaga oksida. (Farida, 2012) sedangkan ketangguhan logam las turun apabila kadar oksigen di dalamnya naik, selain itu bahan utama yang terdapat pada fluks jenis serbuk besi meliputi antara $15-50 \%$ adalah silikat dan serbuk besi (Wiryosumarto, 1988).

\section{Hasil Uji Struktur Mikro}

Dalam sifat mekanik logam, apabila kadar karbon meningkat maka transformasi austenit menjadi ferit akan menurun dan akan mencapai minimum pada titik prosentase karbon $0,8 \%$ pada temperatur $723^{\circ} \mathrm{C}$.

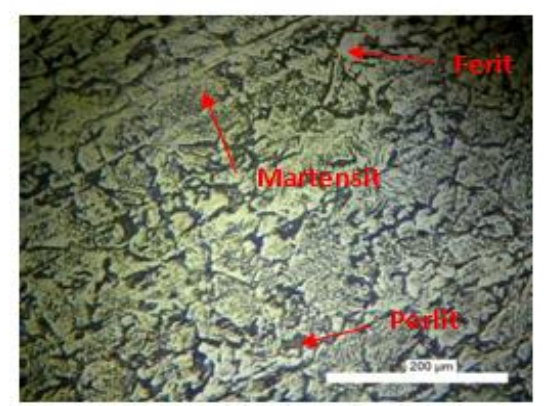

Gambar 4 struktur mikro baja St 60

Gambar 4 menunjukkan struktur mikro dari kandungan baja $\mathrm{St} 60$, di mana butiran martensit sangatlah tinggi, dan juga struktur perlit yang hampir mencapai $45 \%$. Jika di bandingkan dengan struktur martensit selisihnya hanyalah sedikit karena diantara struktur martensit dan perlit, terdapat pula butiran ferit. Kandungan ferit inilah yang membentuk sifat ulet pada material mula, namun kandungan perlit dan juga martensit menjadikan material menjadi keras.

\section{Struktur mikro pada media pendinginan Oli, Udara, Air laut dengan elektroda E 6013 NK \\ Penggunaan oli sebagai media} pendingin akan menyebabkan timbulnya selaput karbon pada spesimen yang tergantung pada besarnya viskositas. (Saputra dkk, 2014) seperti yang nampak pada Gambar 5a Dimana struktur ferit lebih tinggi dibandingkan dengan kandungan perlit dan juga sementit pada logam induk. Pada Gambar 5a dimana terjadi penurunan butiran ferit dan bertambahnya butiran sementit yang lebih banyak sehingga kekerasan material pada daerah logam las lebih tinggi jika dibandingkan dengan logam induknya. untuk daerah HAZ material menjadi 
ulet, karena penurunan butir sementit yang sangat banyak.

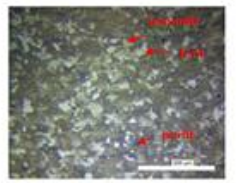

Gambar 5 a

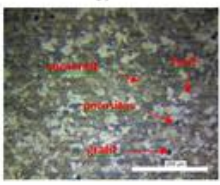

Gambar 5 b

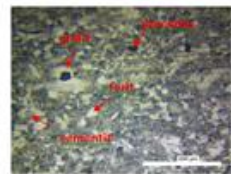

Gambar 5 c

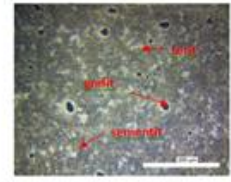

Gambar 6 b

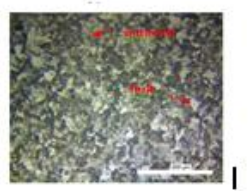

Gambar 6 b

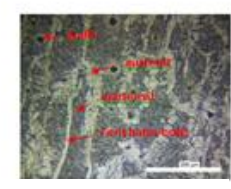

Gambar 6 c
Gambar 5 struktur mikro logam induk dan 6

logam las elektroda E6013 NK

pembahasan struktur mikro pada media pendingin berupa oli, udara dan air laut yang dapat dilihat pada Gambar 5(a)-5(c) logam induk dan 6(a)-6(c) logam las setelah pengelasan dengan media pendingin (a) oli, (b) udara, (c) air laut.

Gambar $5 b$ berupa keadaan logam induk setelah melalui proses pengelasan dan juga pendinginan berupa udara. Dimana struktur ferit lebih tinggi dibandingkan dengan kandungan perlit dan juga sementit dan terjadi porositas pada logam induk cukup tinggi. Sedangkan pada logam las terdapat butiran sementit namun, terdapat pula butiran ferit yang lebih kasar serta porositas yang menurun, shingga meskipun material pada logam las sedikit lebih keras akan tetapi tingkat kerapuhannya rendah. Tidak terjadai perubahan yang tinggi pada daerah HAZ, hanya saja pada daerah HAZ struktur ferit yang terbentuk lebih sedikit daripada struktur ferit yang terbentuk pada logam las. Gambar $6 \mathrm{c}$ adalah hasil mikro dari pendinginan air laut, Air mengandung garam memiliki viskositas yang rendah sehingga laju pendinginannya cepat. Massa jenisnya juga lebih besar dibandingkan dengan media pendingin lain seperti air, solar, oli dan udara. Hal ini dikarenakan adanya kandungan seperti Sulfur, magnesium dan lainnya yang terdapat pada air laut, Saifullah (2013).
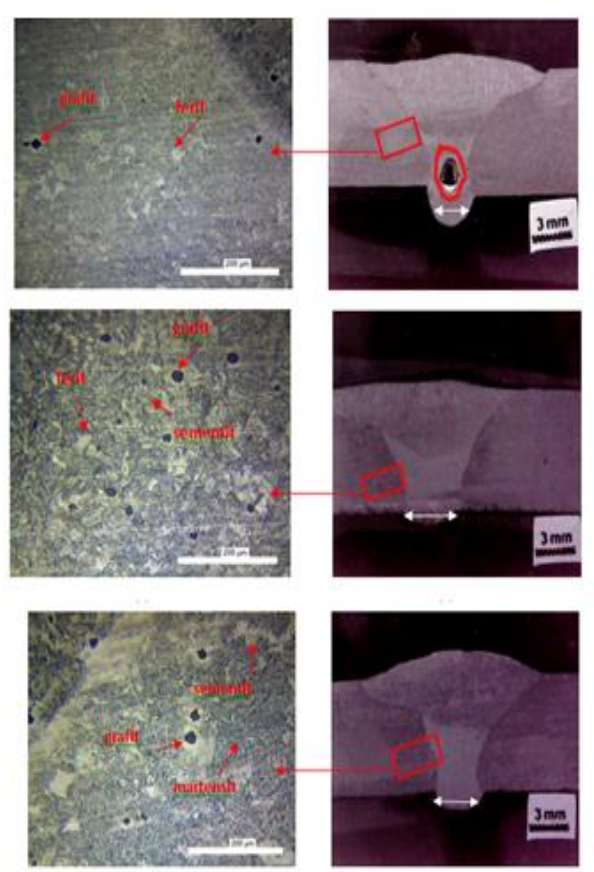

Gambar 7 dan 8 struktur daerah Haz dan foto makro

\section{Struktur mikro pada media pendingin oli, udara, air laut dengan menggunakan elektroda E7018 LB}

metode penjelasan yang hampir sama pada pembahasan sebelumnya. Untuk struktur mikro pada pendinginan oli masih sama dengan penggunaan elektroda E6013 NK dimana dari ketiga media pendingin hasil kekerasan paling tinggi pada pendinginan oli karena terdapat butiran perlit dan juga sementit yang begitu padat Hasil yang mengejutkan terjadi pada kekuatan tarik dengan penggunaan elektroda E7018 LB yang di dinginkan dengan air laut. Jika ditinjau dari hasil mikro, logam induk pada pendinginan air laut memiliki sifat yang cukup ulet karena terdapat butiran ferit yang lebih padat jika dibandingkan dengan butiran perlit. 


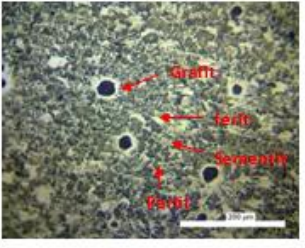

$6 a$

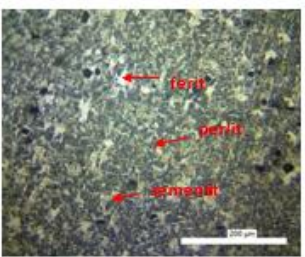

$6 b$

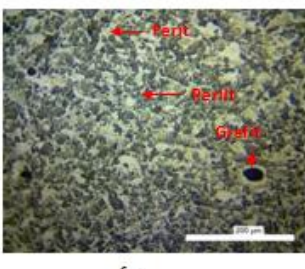

oc
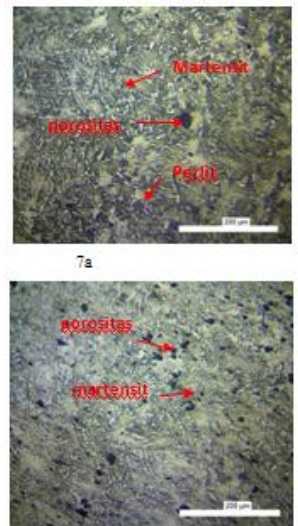

$7 \mathrm{~b}$

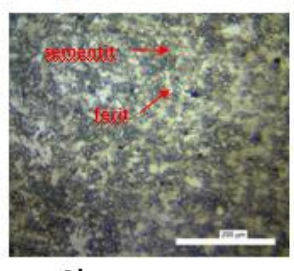

$7 \mathrm{~d}$
Gambar 9dan 10 logam induk dan logam las elektroda E7018 LB
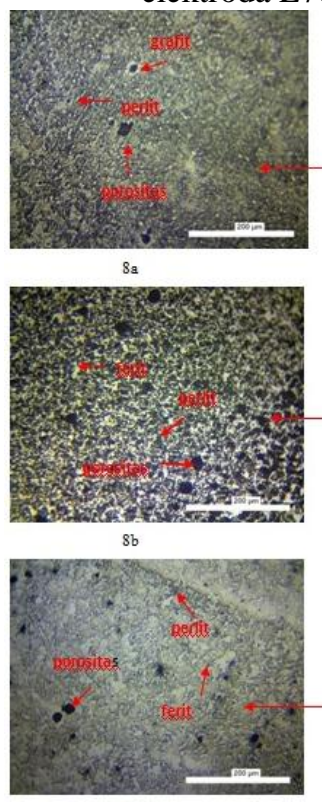

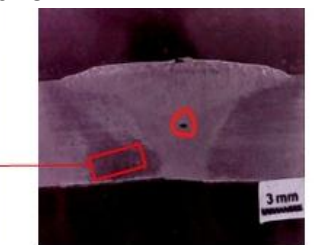

9의
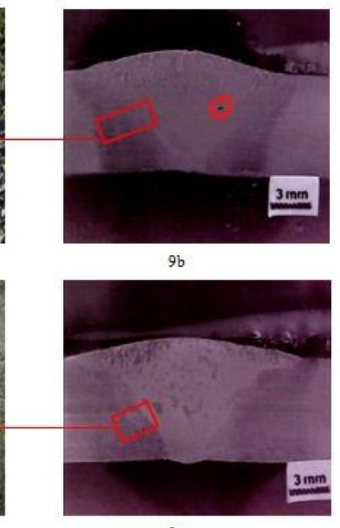

Gambar 11 dan 12 struktur mikro daerah HAZ elektroda E7018 LB

Faktor lain yang menjadikan nilai tegangan tarik pada pendinginan air laut tinggi adalah besar porositas yang terdapat pada material, juga kandungan elektroda E7018 LB berupa serbuk besi yang terdapat 15-50 \% adalah silikat yang pada pembahasan hasil uji tarik dijelasakn bahwa ketangguhan las akan menurun jika kadar oksigen yang terkandung mengalami kenaikan. Usaha penurunan oksigen ini dapat dilakukan dengan penambahan unsur seperti Si, Mn dan Ti. (Wiryosumarto, 1988) Dan kandungan silikat pada elektroda E7018
LB sangat tepat jika di pertemukan dengan sifat hidrogen yang reaktif.

Seperti yang sudah di ketahui bahwa konstruksi pada kapal sangatlah membutuhkan tingkat persyaratan keamanan yang tinggi, dari beberapa pengujian yang telah dilakukan, perubahan kekuatan tarik baja st 60 setelah dilakukan pengelasan tidak mengalami penurunan yang tinggi untuk nilai kekuatan tariknya.

Jenis plat yang dapat digunakan dalam kontruksi kapal meliputi SS 400, ASTM A572, ST 52-3 dan lain-lain dengan tebal: mulai dari 6 $\mathrm{mm} \mathrm{s} / \mathrm{d} 100 \mathrm{~mm}$, lebar : $1500 \mathrm{~mm} \mathrm{~s} / \mathrm{d} 2700$ $\mathrm{mm}$, panjang : $6 \mathrm{~m} \mathrm{~s} / \mathrm{d} 13 \mathrm{~m}$. Sifat mekanis yang karus dimiliki untuk plat kapal biasa adalah : batas lumer $24 \mathrm{~kg} / \mathrm{mm}^{2}$, kekuatan tarik $41 \mathrm{~kg} / \mathrm{mm}^{2} \mathrm{~s} / \mathrm{d} 50 \mathrm{~kg} / \mathrm{mm}^{2}$, dan regangan patah minimal $22 \%$. plat kapal tegangan tinggi (untuk lambung kapal) memiliki sifat mekanis : tegangan lumer minimal $32 \mathrm{~kg} / \mathrm{mm}^{2}$ dan kekuatan tarik $48 \mathrm{~kg} / \mathrm{mm}^{2} \mathrm{~s} / \mathrm{d} 60 \mathrm{~kg} / \mathrm{mm}^{2}$ untuk tegangan lumer minimum $36 \mathrm{~kg} / \mathrm{mm}^{2}$, kekuatan tariknya $50 \mathrm{~kg} / \mathrm{mm}^{2} \mathrm{~s} / \mathrm{d} 63 \mathrm{~kg} / \mathrm{mm}^{2}$, selain itu juga digunakan baja tempa yang memiliki kekuatan tarik minimal $41 \mathrm{~kg} / \mathrm{mm}^{2}$. Baja untuk konstruksi kapal biasanya mengandung 0,15-0,23\% kandungan unsur karbon. Sedangkan untuk kandungan fosfor dan sulfur kurang dari $0,05 \%$. Jika kandungan fosfor dan sulfur terlalu tinggi dapat merugikan pengelasan dari baja dan dapat terjadi keretakan jika mengandung sulfur yang tinggi (Sanjaya, 2012).

Berdasarkan kutipan dari analisa yang sudah dilakukan. Untuk secara material, kandungan yang terdapat dalam baja st 60 adalah seperti terlihat pada Tabel 2

Tabel 2 Data Hasil Uji Komposisi Baja St 60 (Effendi, 2009)

\begin{tabular}{llll}
\hline Unsur & $\begin{array}{l}\text { Komposisi } \\
(\mathbf{\% )}\end{array}$ & Unsur & $\begin{array}{l}\text { Komposisi } \\
(\boldsymbol{\%})\end{array}$ \\
\hline $\mathrm{Fe}$ & 98,46 & $\mathrm{~V}$ & 0,00 \\
$\mathrm{~S}$ & 0,011 & $\mathrm{Mn}$ & 0,697 \\
$\mathrm{Al}$ & 0,000 & $\mathrm{Mo}$ & 0,006 \\
$\mathrm{C}$ & 0,564 & $\mathrm{~W}$ & 0,03 \\
$\mathrm{Ni}$ & 0,36 & $\mathrm{P}$ & 0,006 \\
$\mathrm{Nb}$ & 0,01 & $\mathrm{Cu}$ & 0,004 \\
$\mathrm{Si}$ & 0,142 & $\mathrm{Ti}$ & 0,00 \\
$\mathrm{Cr}$ & 0,040 & & \\
\hline
\end{tabular}

Agar lebih spesifik lagi maka diambil hasil komposisi dari salah satu jenis plat yang tergolong kedalam standart klasifikasi perkapalan Indonesia (BKI) dalam hal ini dapat dilihat hasil uji komposisi baja SS 400 pada Tabel 3 
Tabel 3 Data hasil uji komposisi baja ss 400 (Febri, 2011)

\begin{tabular}{|c|c|c|c|c|c|c|c|}
\hline $\mathrm{C}$ & $\mathrm{Si}$ & $\mathrm{Mn}$ & $\mathrm{S}$ & $\mathrm{Ni}$ & $\mathrm{Cr}$ & $\mathrm{P}$ & $\mathrm{Fe}$ \\
\hline 0,20 & 0,09 & 0,53 & 0,04 & 0,03 & 0,03 & 0,1 & Balance \\
\hline
\end{tabular}
sekitar $60 \mathrm{~kg} / \mathrm{mm}^{2}$, hal ini cukup baik apabila dijadikan bahan alternatif untuk plat kapal jika di lihat dari syarat batas kekuatan tariknya. Dari segi kandungan materialnya pun untuk nilai fosfor dan sulfur tidak melebihi dari $0,05 \%$. Itu berarti baja St 60 boleh digunakan hanya untuk kontruksi kapal dengan tekanan yang kecil.

\section{KESIMPULAN}

Berdasarkan hasil penelitian yang dilakukan tentang pengaruh jenis elektroda dan media pendinginan terhadap kekuatan tarik dan struktur mikro baja St 60, maka dapat di tarik kesimpulan yang sebagai berikut :

1. Jenis elektroda E6013 NK nilai kekuatan tarik tertinggi yaitu sebesar $57.016 \mathrm{~kg} / \mathrm{mm}^{2}$ dengan pendinginan udara, hasil tersebut hampir mendekati material asli atau raw material dengan nilai kekuatan tarik sebesar 57.507 $\mathrm{kg} / \mathrm{mm}^{2}$. Sedangkan untuk jenis elektroda E7018 LB, kekuatan tarik rata-rata tertinggi justru pada jenis pendinginan air laut yang mencapai nilai tegangan tarik hingga 55.228 $\mathrm{kg} / \mathrm{mm}^{2}$

2. Media pendinginan udara dengan Elektroda E 6013 NK merupakan hasil foto mikro yang terbaik karena tidak terjadi porositas yang tinggi.

3. Plat baja St 60 dapat digunakan sebagai bahan alternatif konstruksi kapal hanya di bagian yang terkena tekanan kecil.

\section{SARAN}

1. Juru las haruslah berpengalaman

2. Untuk mengurangi porositas sebaiknya logam yang akan di las harus benar-benar bersih

3. Pada saat pembuatan kampuh "V" hal yang perlu diperhatikan adalah jarak antar dua buah benda kerja (gap/root gap) karena hal ini dapat mempengaruhi hasil penembusan las (root weld)

4. Sebaiknya gunakan anti defleksi agar spesimen ketika di las tidak mengalami perubahan bentuk atau defleksi yang berlebihan.
5. untuk penelitian selanjutnya, sebaiknya dilakukan perlakuan material untuk plat baja St 60 dengan menyesuaikan kebutuhan konstruksi kapal.

\section{DAFTAR PUSTAKA}

Effendi, N., (2009), "Studi Pengaruh Heat Input Terhadap Ketangguhan Impact Las SMAW Posisi Vertikal Baja ST 60 Temper", Jurnal Traksi Vol.9 Jurusan Teknik Mesin, Fakultas Teknik,Universitas Muhammadiyah Semarang.

Dinariyana, B, A,A., (2011) Teknik Bangunan Dan Kontruksi Kapal I Fakultas Teknologi Kelautan, ITS, Surabaya.

Febri, B, Y., (2011) "Analisa Sifat Mekanik Hasil Pengelasan GMAW Baja SS400 Studi Kasus di PT.INKA Madiun" Tugas Akhir jurusan Teknik Mesin, ITS Surabaya.

Farida, I., (2012), Kimia Anorganik I. Bandung, CV.Insan Mandiri.

Gapsari, F., Setyarini. P.H., Alamsyah F.A., 2012, "Pengaruh Kekasaran Permukaan Terhadap Porositas Hasil Hot Dipped Galvanizing (HDG)" Jurnal Rekayasa Mesin Vol.3 Fakultas Teknik, Universitas Brawijaya, Malang

Hanafi, A., (2012). Pengaruh Jenis Media Pendingin terhadap Kekuatan Tarik Sambungan Logam Las Plat Baja St-60 Dengan Pengelasan MIG/MAG, Jurusan Teknik Mesin, Fakultas Teknik, Universitas Negeri Malang, Malang

Haryadi, G.D., (2007), "Analisi Kerusakan Hasil Pengelasan Bawah Air Pada Lambung Kapal Dengan Elektroda RB 26 Terseletip", jurnal Rotasi - Volume 9 Jurusan Teknik Mesin, Fakultas Teknik, Universitas Diponegoro, Semarang.

Sanjaya, R.,(2012), Konstruksi kapal, Teknik Bangunan kapal ITS, Surabaya.

Saputra, H., Syarief.A., Maulana.Y., (2014), "Analisis Pengaruh Media Pendinginan Terhadap Kekuatan Tarik Baja ST37 Pasca Pengelasan Menggunakan Las Listrik", Jurnal Ilmiah Teknik Mesin Unlam Vol. 03 Fakultas Teknik Universitas Lambung Mangkurat, Kalimantan Selatan.

Sunaryo, H., (2008), Pengelasan kapal Jilid II : Penerbit Direktorat Pembinaan Sekolah Menengah Kejuruan, Dirjen Manajemen 
Pendidikan Dasar dan Menengah, Departemen Pendidikan Nasional.

Suprijanto, D., (2013), "Pengaruh Bentuk Kampuh Terhadap Kekuatan Banding Las Sudut SMAW Posisi Mendatar Pada Baja Karbon Rendah". Seminar nasional ke 8, Jurusan Teknik Mesin STTNAS Yogyakarta.

Saifullah, (2013), Oseanografi Fisika kimia air laut, Jogjakarta

Supriyanto, Ismanto., Silva, H.A., (2011) Pengaruh Variasi Cuaca Terhadap Ketangguhan Hasil Lasan Pada Baja Karbon Rendah, 1Dosen Jurusan Teknik Mesin Fakultas Teknik Universitas Janabadra ,Jurusan Teknik Mesin Fakultas Teknik Universitas Janabadra

Wiryosumarto, H., Okumura.T., (1988), Teknologi Pengelasan Logam, Pradnya Paramita, Jakarta. 